\title{
Challenges of Women Entrepreneurs in Albania
}

\author{
Erinda Imeraj \\ E-mail: eimeraj@epoka.edu.al \\ Sonila Gruda \\ E-mail: sgruda@epoka.edu.al
}

\section{Doi:10.5901/mjss.2013.v4n11p467}

\begin{abstract}
"Entrepreneurship is neither a science nor an art. It is a practice!", P.Ducker. In support of this inspirational quote about entrepreneurship our frame work aims to underline the women potential to enter and succeed in the own business area. The paper analyses the current situation of women entrepreneurs in Albania. On the other side this research outlines the key concepts of women entrepreneurs by showing current statistical data. The reasons why the women should be part of the entrepreneurship field are compared with the social issues of the Albanian mentality. There are many challenges that women should face in this initiative, which are worldwide known issues, in particular considered for Albanian case. In Albania, there are many women leaded organizations which support the development of women leaders, considering the government, international and national actors.
\end{abstract}

\section{Introduction}

Being a woman in business today, in Albania, is something that in the past was never possible. Even now this fact constitutes a major difficulty for the business categories they are able to commit, which shouldn't be the only faced problem in a series of troubles. Business women are an inalienable part of the Albanian business. Flutura Xhabija, president of the Association of Professional \& Business women Says: To exhibit their work and skills in this regard opens a second edition of the concept called "Female entrepreneurship Spirit". About 62 firms have female entrepreneurs, mostly embroidery products, trading firms, etc., included in a wide geography, ranging from Shkodra, Gjirokastra, Korca, Pogradec Maminas, and many other cities. According to the state statistics $80 \%$ of the women businesses are ranged as small business because most of the large or medium-sized businesses are owned by men. Even if the women's businesses are small, they are able to provide quality and enough support for themselves. They are still at the stage of complaining the facilities and opportunities to have a business owned alone. Many women associations show that women have not yet reached a balance between business problems and family problem. Generally women get lost because of the limited time to deal with the concern. Business is difficult and has very little space to make mistakes because as many of them confirm in Albania is a matter of mentality. Women innovators is a simple business-oriented set of connections that provides knowledge and inspiration for this successful business owners in Albania. There are many projects initiated by the head of the Albanian Parliament Mrs. Jozefina Topalli. In these movements she aims to raise the ambition and support the women businesses because Albania must increase the number of companies established by women. These programs offer mentoring by the local legal partners, training and offer short workshops. These leaders must strive to provide useful tips and information on the organization. The manufacturing sectors need inspired entrepreneurs not only actual and potential, but also offering practical tools that can be incorporated into business entrepreneurs. Women are a huge asset that contributes to the economy but also in family income. Our research wishes to reach out to as many women and contribute to them in order for them to see the opportunities that are offered to create their business. There are 65 per cent informal employment in Albania consists of women, while men are less employed in black market, with only 35 percent, according to the World Bank report. About 20 per cent fewer women than men are paid on average in the Western Balkans. In Albania there are very few women or businesswoman who owned a private business. The World Bank report states that in Europe finds significant disparities in this spectrum. According to EU the countries with the lowest levels of female ownership in business are Albania, Azerbaijan and Kosovo (11 percent). According to INSTAT, the number of active businesses in 2010 amounted to 100.600 businesses where $26.4 \%$ are owed or managed by women. During 2010 the number of active businesses was 106.477 , of which $25.7 \%$ 
were led by women. According to the Bank of Albania, of the total crediting for 2010 shows that: $31.4 \%$ was obtained from businesses that are owner or managed by women. Albanian government decided to implement the Business and Investment Strategy for 2007-2013, approved by the regulation Nr.795, dated 11.07.2007. The strategic program for the development of SMEs for the period 2007-2009 aims to promote the competitiveness of SMEs focused on female labor. The strategy has a meeting point on supporting entrepreneurship culture in improving the business climate, increase competitiveness and improve SME financing programs to promote women's participation in business.

\section{Concept of women entrepreneurs}

Women Entrepreneurs may be individualized as the women or a group of women who start, arrange and activates a business enterprise. The Government of Albania has defined women entrepreneurs as an important and main chain for having an increase firstly in the labor force. The women in Albania show that accepts the things that she doesn't know because nobody knows all the required information to run a business. It is important to understand what you already know, what you don't know and how to fill the latter. Many investigations showed that females usually talk to the same gender about business if they need help to expand a company plan. They are opened to ask frequently for the steps they need to provide and particularly their simplicity makes an advantage. Their softness will save a lot of time in plan techniques and avoid some wrong steps commonly. On the other side for the design of the plans women showed to be more understandable than mans as for example in consumer marketing, because "they cannot put hand in the fire for nothing". After they create the plan they are more intelligent to communicate with others in order to get a feedback of their thoughts. Usually they seem to be prepared to change their minds. When they get feedback, women leader never hesitates to change the original plan. Women entrepreneurs engaged in business due to push and pull factors which encourage women to have an independent occupation enable them to stand on their own legs. There is an intellect sovereign in decision-making on their life and career is a motivating factor behind any recommendation. Under the many pressure of factors the women entrepreneurs choose to be profession and do something new. Such a situation is described as pull factors. While in push factors women occupied in business activities due to family compulsion and the responsibility is drive upon them. Entrepreneurs can be both women and men, but there are factors that distinguish, such are:

* Technological Development - New technologies enables the development of products and creates opportunities for new business and these modern technology, information or communication decrease labor costs. But research shows that entrepreneurial women rarely choose to run the high-tech businesses.

* Economic factors - are economic development, high rate unemployment, lack the level of service sector development, economic transactions as Albanian Economic situation etc.. All these economic issues bring a lack of entrepreneurship because it reduces even the economy's largest companies. Females with underdeveloped economies falter have no opportunity to open new business.

* Demographic factor - are woman's family status, age, education, ethnicity, etc.. Family status matters because women are more likely to own double businesses difficulties.

* Other factors - are considered the experience of women, unequal status of women in relation to men that are a question of opportunities. On the other side credit gain from banks in order to start personal company usually female leader have lack of knowledge for bank issues and business management areas.

\section{Reason for women becoming entrepreneurs}

The main obstacle that women may have to enter in business sector is exactly the confidence they have in themselves and which seems to take them one stepped back. The problem is not always the laws or policies of the country towards business, but that women should have the self-confidence to do so. On the other side the knowledge and the skills are an important issue that a woman doesn't lead in innovation. Women showed that her character is full of challenging to gather personal needs. They are more careful in business issues and the sense of sincerity it's more common. In Albania the women entrepreneurs started business due to the contribution of social and healthier family situations. Women entrepreneurs have to face a hard competition with the men entrepreneurs who are easily involve in the development areas to carry out their products. Such a competition ultimately results in the bankruptcy of women entrepreneurs. As in many situations, the choice to work has its advantages and disadvantages, especially when it comes to the female subject, which is a specific stages of life is more difficult to give up some family priority because of the profession work and the possibility to make a career out of the walls of the house. The growth of children and family commitments are the 
priority for the woman who decides to create a family, but it is only a matter of time, and on this logic women should support the professional commitment. Women entrepreneurs are providing professional contributions for all potential and internal possibilities. Staying at home and see how others work on a day filled with commitments, makes these women feel empty and without value. Economic independence is another issue that stimulates females to open businesses. By working they provide economic independence and personal income which of course is a direct contribution to the family, but first of themselves. Economics independence is what marks the first equality between partners and gives more meaning to the relationship.

Other reasons are:

* They can make decisions most of the time without taking permission

* They contribute financially to the family, society and economy

* They encourage children to be educated with work

The business or the new organization aims to develop the sense of accomplishment. Besides the role of wives and mothers, even when there are sufficient economic opportunities, a woman who owns a business feels fulfilled and completed in all the roles that she carries, as a wife, mother, woman, wife and friend. Work is a very important aspect of to empower human relations. On the other hand business mothers are model for children. An important element for the mothers who exercise a professional career is and role of model that they provide for their children. When they grow up in the pace of the work of the parents, there are many opportunities to develop a personal ethic for work. Thus, children learn the value of the work, money and household consumption. In this way, when both parents work, the children see the division of duties and responsibilities equally between each other. Men appreciate women who own business. This concept came out from many slogans of female rights that stat gender equality. Relationship in pairs becomes even more stimulating when partner drew its independence, independence which enables them to be stronger. The role of women in the business is becoming in a wide social network. Dynamics of life outside the walls of the house without a doubt makes women feel more fulfilled and social life. Business gives them the opportunity to expand the friendship, knowledge and presence in various activities outside the work environment. Innovation world offers us endless opportunities to be updated with the latest news in many areas of life.

\section{Challenges of Women Entrepreneurs in Albania}

"An entrepreneur tends to bite off a little more than he can chew hoping he'll quickly learn how to chew it!" What if we are talking about a woman entrepreneur?!

Entrepreneurship isn't about having a walk, but it goes too much further if you are part of the women persuasion. Even with the advance made on the support of the women and the hand given to their initiatives, the situation differ form man entrepreneurs to women entrepreneurs. The difficulties women do face on their business way are much more than the man's. The history, past facts and studies but also real surveys made on the Albanian market and the entrepreneur field, have introduced a list of challenges and difficulties that an Albanian women should face and pass out in order not to turn back, but to succeed in the entrepreneurship.

According to studies made in the world women entrepreneurship situation the conclusion goes to five most important challenges. The fist deals with "Not being taken seriously", the women's opinion and advices are not taken as expert compare to the man's. In every forward step taken from the women the first support does not go to the initiative, but each step is considered as a hobby or support activity and in no way as a productive and beneficial business or enterprise.

Second challenge deals with the "Letting fear aside". This challenge is part of the character of the women, it is difficult for them to let the fear of each step, of failure, fear of success etc, to stand out in the way and get into the real work. Confidence is a great way to combat these fears and the best way to feel confident in what you are doing is to make sure that you are as prepared as possible before you start your business endeavor. Also, believe in what you bring to the table and value your time, efforts and capabilities.

Third challenge is the women's "desire to please everyone". The fragile character and the politeness that women possess put them in difficult situations when it comes to lead, to ask and to please. They are educated to be polite and this come to waste of time and energy to achieve what they want on what has to be done in the pleasing way. The answer "No" is very difficult for women to be said too, so this typically comes at the expense of their own needs, business or otherwise.

"Wearing to many hats" is the fourth challenge. Women are used to be each person and hand to each person. So they are used to be what other wants to each of them. Wearing to many hats is called, and in the moment that 
"enterprise" or "own business" is added to the mix, this makes a harder time to them and adds the difficulties. "Women can feel like they have to "do it for themselves" or are the best person for every job and have a tougher time delegating responsibilities to others. This causes more time to be spent working in their business, rather than on their business. This is a major hurdle to overcome in order to have a successful business."

"Being proud of success" and speaking out loud the achievements are part of a business and successful one. But women are not used to do this and they feel uncomfortable talking about their achievements and promoting them to the others. But your achievements and accomplishments are some of the biggest selling points your business has, so don't be afraid to put them out there!

These were five of the most important challenges, but if we talk about a small country as Albania is, and with an economy in transition, the difficulties rises and the challenges are not any more this general but they goes more indeed. Many surveys are made and many statistics are analyzed, there can be seen that there is a small percentage of women being hard working and successful on enterprises, highly educated, married and with children and very capable on their way.

The basic difficulties start with the "Financial Assistance". One of the main obstacles encountered is the lack of financial support both from State and private banks, and from institutions and funding foundations as a whole. It is noted that about 50 per cent of women entrepreneurs wish to receive financial backing to expand their firms.

The legal background is the other next difficulty. The policies of the Albanian economy, mostly the tax policies do not stimulate the new businesses, and most of the women entrepreneurs complain for the non sense responses they get from the duty offices and not understandable proceedings they should follow to be in accordance with the law and regulations.

Information, one of basic obstacles not just in the business are but in many other. There are no public institutions to which one can turn for current information on business development.

The social environment is part of the difficulties. Women entrepreneurs tend to be discouraged by a hostile and distrustful environment. Several factors of a social, cultural and psychological nature have led many people to believe that women are devoid of the managerial capabilities required for the successful management of a business. This attitude is hardly likely to change in the short term.

Managerial Capabilities, is a difficult named as this just because of the lack of the self confidence the Albanian women do have compare to the men. Running an enterprise needs to take risks, that is none of women nature. Many are unfamiliar with marketing techniques, or do not possess the experience and ability needed to expand their businesses, or sell other products, or to diversify. They often find it hard to draw up, prepare and present a business plan. Here great assistance has been provided by other NGOs, such as the "Promotion and development of small and medium-sized enterprises" project of the German GTZ in Tirana, the regional development agencies operating in several towns, and the UNDP-backed "Promotion of small and medium-sized enterprises and the possibilities of creating new jobs" project at Fier and Berat.

Mobility, which goes parallel to the Albanian culture and mentality, is another difficulty of women entrepreneurs in Albania. A considerable percentage of women have difficulty in travelling alone, even though situation is in change, mainly due to the chaos during the economic and political crisis. Moreover it can be said that Albanian women are "not supposed" to travel alone. If they dare to do so, they may the subject of adverse reactions, molestation or robbery, and they have greater fears than men who travel alone. The problem of getting around is of greater consequence for women who live outside Tirana and have to come into the capital for supplies.

Instability, said for the general situation, highlights a great pressure of women difficulties. Civil disorder has resulted in the closure of many businesses run by women and discouraged the others to commence businesses. According to the survey made from the International Labor Organizations for Albania, examination of the reasons why businesses close down throws light on the difficulties that face women as entrepreneurs in Albania. Lack of funds was responsible for 36.4 per cent of shutdowns, whereas 29.6 per cent of women gave up due to external non-business (gender-related) factors such as marriage or divorce. In other cases, women entrepreneurs have been compelled to close because the land on which their enterprise was situated was repossessed by the former owner. Other closures have been rendered necessary by a lack of customers (13.6 per cent) or arising from management problems (12.7 per cent).

\section{Supporting Organizations}

Women entrepreneur as there is figured out above, have many difficulties and through success in the own business area. 
The democratic governments and developed ones have started too early to support women in their initiatives and have reached to get productive results. Manu international organizations are the right hand of women now a day. In Albania too, after 1990, many national and international organizations are helping in the women entrepreneurs' area, among the bodies that support women in business is; The government through the Women Department established in 1992, currently named "Women and Family Committee" under the supervision of Council of Ministers. It aims to foster women participation in all spheres of life via the development of social policies, improvement of legislation, co-operation with local governments. The range of issues that it is dealing with is broader than women and business. In the framework of assistance and promotion of women participation in business it has conducted three training courses, sponsored by the government and international organizations like UNDP. EU, ILO. Beneficiaries have been businesswomen and NGO-s. Main foreign institutions and agencies that have provided support to women businesses:

USAID, through project has been one of the main donors for business the strategy and plans for development of women via the Committee"Women and Family". SNV (The Netherlands Development Organization), EC through the PHARE program has financed several projects of women NGO-S, GTZ, the German project for support of SME-s has offered assistance for the support, training and promotion of 192 women entrepreneurs. SOROS Foundation (OSFA) supports the women NGO-s activities through the Women Programs.

There is a considerable number of NGO's in Albania that operates with the aim of helping, training and supporting, most of them with direct intent with women support.

Nevertheless, as a matter of fact, the women movement in support to women entrepreneurs is becoming more massive and consolidated. The positive trend for increasing the number of branches in other districts has to be followed by the increase of the membership. The NGO-s are becoming more and more as representatives of specific interest of women entrepreneurs of those that aim to start a women business and of women that want to improve the managerial skills, before being engaged into a real business.

\section{Conclusion}

Women are strong and their character may handle a lot more than is usually thought. Women may be successful and sometimes more than men do. There are a lot of challenges that women entrepreneurs have to face and all the above listed do have a part in the Albanian women entrepreneurs. From year to year things have changed and been better. Much more will be done and without the proper support women are too fragile to be alone, at least let them know that in any situation the support is near.

\section{References}

Anamali A. (2009), Job Quality and Small Enterprise Development.

Bezhani M. (2001), Women Entrepreneurs in Albania, Series on Women's Entrepreneurship Development and Gender in Enterprises WEDGE, SEED Working Paper No. 21,

Edwards A. D. (2012), Women Entrepreneurs Access to Finance in the Developing World, RIBM Doctoral Symposium.

Hafizi M. (2002), Female Entrepreneurship in Republic of Albania, International Symposium on Learning Management and Technology Development in the Information and Internet Age, University of Bologna.

INSTAT (2010) Statistical Yearbook 2004-2013, Albanian National Institute of Statistics. Tirane, Albania.

Kalim A., Women Entrepreneurship The Emerging Workforce in 21st Century: Turning Challenges into Opportunities, Innovative Educational Solutions (IES), Lahore.

Kurukshetra Sh. (2012), Women Entrepreneurship in India, International Indexed \& Referred Research Journal.

Xhabija F. (2011), Jobs, Gender and Small Enterprises in Albania: Series on Women's Entrepreneurship Development and Gender in Enterprises. 